\title{
Laminin concentration in ascites of patients with hepatic cirrhosis and peritoneal carcinomatosis
}

R.M. Catarino ${ }^{1}$ J.D. Lopes², N.M. Forones ${ }^{1}$ and E.R. Parise ${ }^{1}$

\author{
Disciplinas de ${ }^{1}$ Gastroenterologia and ${ }^{2}$ Imunologia, \\ Escola Paulista de Medicina, Universidade Federal de São Paulo, \\ São Paulo, SP, Brasil
}

\section{Correspondence \\ E.R. Parise \\ Disciplina de Gastroenterologia \\ EPM, UNIFESP \\ Rua Botucatu, 740, 2ㅇandar \\ 04023-000 São Paulo, SP \\ Brasil \\ Fax: +55-11-5572-5945 \\ E-mail: parise@gastro.epm.br \\ Publication supported by FAPESP.}

Received March 10, 2004

Accepted November 8, 2004

\begin{abstract}
Laminin levels in ascitic fluid have been proposed as a marker for neoplastic ascites. We compared the concentration of laminin in serum and in ascitic fluid from patients with hepatic cirrhosis and peritoneal carcinomatosis and assessed the diagnostic value of serum laminin levels in differentiating neoplastic from benign ascites. Laminin concentrations were determined by ELISA with antibodies against laminin extracted from the human placenta, in patients with ascites due to peritoneal carcinomatosis $(\mathrm{N}=20)$ and hepatic cirrhosis $(\mathrm{N}=$ 33). Patients with infected or hemorrhagic ascites were excluded. The receiver operating characteristic curve was used to determine the sensitivity and specificity of serum laminin for the diagnosis of neoplastic ascites. When compared to the group with cirrhosis, the carcinomatosis group presented significantly higher mean laminin levels in serum ( $3.3 \pm 0.5 v s 2.1 \pm 0.4 \mu \mathrm{g} / \mathrm{ml}$, mean $\pm \mathrm{SD}, \mathrm{P}<0.05)$ and ascites $(2.8 \pm 0.5 v s 1.6 \pm 0.4 \mu \mathrm{g} / \mathrm{ml}, \mathrm{P}<0.05)$. Although laminin concentration was higher in serum than in ascites, the laminin serum/ ascites ratio and serum-ascites gradient did not differ between the studied groups. A significant correlation $(r=0.93, \mathrm{P}<0.0001)$ was observed between the serum and ascites laminin values. Serum laminin levels $>2.25 \mu \mathrm{g} / \mathrm{ml}$ showed $100 \%$ sensitivity and $73 \%$ specificity for the diagnosis of neoplastic ascites. Serum concentration seems to be the main determinant of laminin levels in ascitic fluid and its values can be used as a diagnostic parameter in the study of neoplastic ascites.
\end{abstract}

\section{Introduction}

Laminin, a basement membrane glycoprotein, participates in a series of biological phenomena such as adhesion, migration, differentiation, and cell growth (1), in addition to the maintenance of essential membrane architecture $(2,3)$. Its serum levels have been
Key words

- Ascites laminin

- Serum laminin

- Peritoneal carcinomatosis
- Cirrhosis 
been attributed to a progressive increase in laminin deposition along the sinusoids during capillarization of the Disse's space $(4,8$, $9)$. Furthermore, increased serum laminin levels are also found in patients with neoplasms, especially in cases of basement membrane alterations associated with tumor proliferation and invasion $(10,11)$. The serum values tend to increase significantly with the emergence of metastases, independent of tumor lineage or neoplasm origin (12-15).

The levels of laminin in ascitic fluid have also been proposed as a neoplastic ascites marker (16), but no systematic study has been reported in the literature.

\section{Patients and Methods}

Twenty-five healthy adult individuals, 10 men and 15 women, with a mean age of $44 \pm$ 15 years (mean $\pm \mathrm{SD}$ ) were studied as a reference population for the quantification of serum laminin (control group).

An additional group of 53 patients (18 to 74 years old), mainly Caucasians (93\%), was included in the study and divided into:

Group 1. Thirty-three patients with liver cirrhosis and ascites detectable on physical examination. The diagnosis of cirrhosis was proven by liver biopsy or based on clinicalbiochemical criteria (17). This group consisted of 21 males and 12 females with a mean age of $47 \pm 12$ years. The cirrhosis etiology for this group was alcoholism (21 cases), viral infection (8 cases), non-alcoholic steatohepatitis (2), $\alpha 1$ antitrypsin deficiency (1), and cryptogenic cirrhosis (1).

Group 2. Twenty patients with neoplastic ascites established by the presence of neoplastic cells in the ascitic fluid and confirmed by the presence of peritoneal implants during surgery or laparoscopy. This group consisted of 9 men and 11 women with a mean age of $60 \pm 14$ years. The sites of primary tumor origin (all adenocarcinomas) were: ovary (8), colon (4), stomach (4), bladder (2), pancreas (1), and uterus (1).
Exclusion criteria were ascitic fluid with cellularity above $250 \mathrm{PMN} / \mathrm{mm}^{3}$ or positive ascitic fluid culture, systemic infectious processes at present or in the last 3 months before inclusion in the study, patients who had been previously treated or were currently being treated with chemotherapy or radiotherapy, macroscopically hemorrhagic ascitic fluid, suspicion of peritoneal tuberculosis based on laparoscopic findings or ascites cellularity.

All patients were informed of the procedures that they would be subjected to and gave their written informed consent prior to inclusion in the study. The study protocol was approved by the Medical Ethics Committee of São Paulo Hospital, Universidade Federal de São Paulo-Escola Paulista de Medicina, São Paulo, SP, Brazil.

After selection, the patients were submitted to abdominal paracentesis and blood was collected from a peripheral vein for serum evaluation. The samples were centrifuged and divided into aliquots and a part was stored frozen at $-80^{\circ} \mathrm{C}$ for laminin determination. Laboratory analysis of the ascitic fluid included total and differential cell counts, total protein and amylase determination, bacterial culture, and oncotic cytology.

Laminin was isolated from human placenta as described by Schechter and Lopes (18). The isolated protein was identified by $5 \%$ SDS-PAGE under reducing conditions and protein concentration was estimated by the method of Bradford (19-21). Total protein extraction from approximately $500 \mathrm{~g}$ of fresh placental tissue yielded $31 \mathrm{mg}$ laminin.

Antiserum was produced in female New Zealand rabbits using monthly intramuscular injections of $100 \mu \mathrm{g}$ purified laminin in complete and incomplete Freund's adjuvants (22). Antilaminin titer was measured by enzyme-linked immunosorbent assay (ELISA) using anti-rabbit IgG conjugated with peroxidase and o-phenylenediamine (23). For the purification of the antibody obtained, 10 mg laminin was coupled to a $\mathrm{CNBr}$-acti- 
vated Sepharose affinity column (Pharmacia, Uppsala, Sweden) and eluted with $0.1 \mathrm{M}$ glycine- $\mathrm{HCl}$ buffer, $\mathrm{pH} 3.0$, containing 0.15 $\mathrm{M} \mathrm{NaCl}$. The final protein concentration obtained was $852 \mu \mathrm{g}$ antilaminin antibody/ $\mathrm{ml}$. The conjugation of the secondary antibody with horseradish peroxidase was performed by the method of Avrameas et al. (24). The purified antibodies were used in an immunohistochemical test with fresh sections of rat liver (25).

Laminin concentrations in serum and ascitic fluid of subjects with peritoneal carcinomatosis and with liver cirrhosis, and in the serum of healthy individuals were tested in triplicate by ELISA. The serum-ascites laminin gradient was calculated by subtracting the ascites values from the serum concentration, while the serum/ascites ratio was obtained by dividing the serum value by the ascites concentration. The receiver operating characteristic (ROC) curve was used to determined the relationship between serum laminin levels and the diagnosis of neoplastic ascites (26).

Statistical analysis was carried out by Kruskal-Wallis analysis of variance complemented by Dunn's test and Pearson's linear correlation coefficient (27).

\section{Results}

The isolated human laminin was characterized by SDS-PAGE under reducing conditions (Figure 1) and by rat liver immunohistochemistry (Figure 2). The electrophoretic profile, purity grade and immunohistochemical results agreed with those reported in the literature (25-29).

Serum and ascites laminin concentrations found in the different groups studied are shown in Table 1. The mean serum laminin values were significantly higher in patients with carcinomatosis and cirrhosis than in individuals from the control group. Furthermore, the values obtained for the ascitic fluid were statistically higher in patients with carcinomatosis than in patients with cirrhosis.

The values of the serum-ascites gradient $(0.5 \pm 0.34$ in the cirrhotic group vs $0.5 \pm$ 0.12 in the neoplastic group, means $\pm \mathrm{SD}, \mathrm{P}$ $=1.00)$ and the serum/ascites laminin ratio $(1.35 \pm 0.29$ vs $1.21 \pm 0.20$, respectively, $\mathrm{P}=$ 0.065 ) did not differ between the two groups (Figure 3). A highly significant correlation was observed between laminin concentrations in serum and in ascites of the patients studied $(r=0.93, P<0.0001$; Figure 4).

ROC curve analysis showed that the area under the curve of serum laminin was 0.967 (0.927-1.008 95\% CI, P < 0.01). For serum

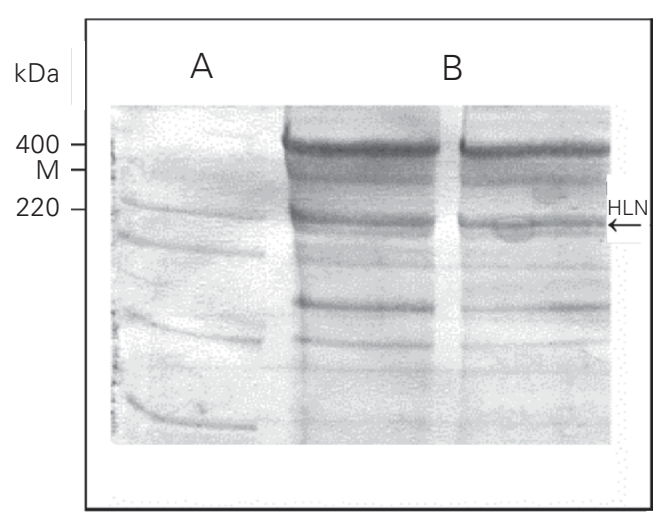

Figure 1. Electrophoresis of laminin in 5\% polyacrylamide gel (SDS-PAGE). Samples with molecular weight standards and laminin purified $(20 \mathrm{\mu g} / \mathrm{ml})$ from human placenta were applied. Protein bands were visualized by Coomassie brilliant blue staining. $A=$ Molecular weight standard (Bio-Rad, Hercules, CA, USA); $B=$ human laminin (HLN, arrow) under reduced conditions. $M=$ subunit of laminin.

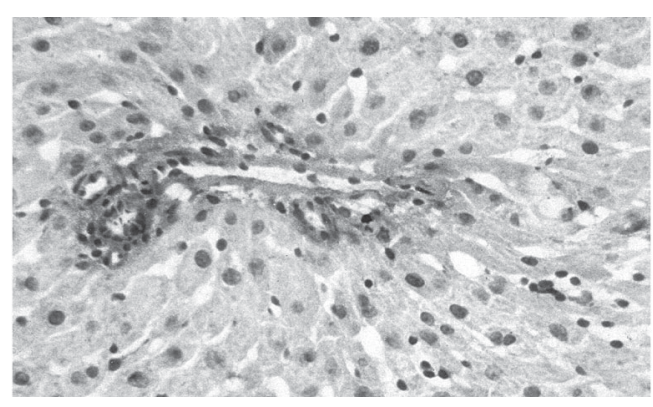

Figure 2. Photomicrograph showing immunohistochemistry of rat liver sections. The expression of laminin detected by anti-laminin antibodies is shown in the portal spaces around the biliary canaliculi, blood and lymphatic vessels. Magnification, 400X.

Table 1. Serum and ascites laminin concentrations in patients with cirrhosis and neoplastic ascites and in control subjects.

\begin{tabular}{lccc}
\hline & $\begin{array}{c}\text { Control subjects } \\
(\mathrm{N}=25)\end{array}$ & $\begin{array}{c}\text { Cirrhotic patients } \\
(\mathrm{N}=33)\end{array}$ & $\begin{array}{c}\text { Neoplastic patients } \\
(\mathrm{N}=20)\end{array}$ \\
\hline Laminin in serum & $0.183 \pm 0.06$ & $2.1 \pm 0.4$ & $3.3 \pm 0.5$ \\
Laminin in ascites & & $1.6 \pm 0.4$ & $2.8 \pm 0.5$ \\
\hline
\end{tabular}

Data are reported as means \pm SD 
laminin values higher than $2.25 \mu \mathrm{g} / \mathrm{ml}$, the diagnostic sensitivity was $100 \%$ and the specificity $73 \%$.

\section{Discussion}

We describe here an uptake assay that utilizes a peroxidase-coupled double antibody system. This test is simple, quick and reproducible and is able to measure laminin levels in serum and ascites. Contrary to what was observed by Smith and Bentsen (16), the response of the test was linear for laminin determination.

Increased serum laminin concentration in patients with chronic liver diseases was

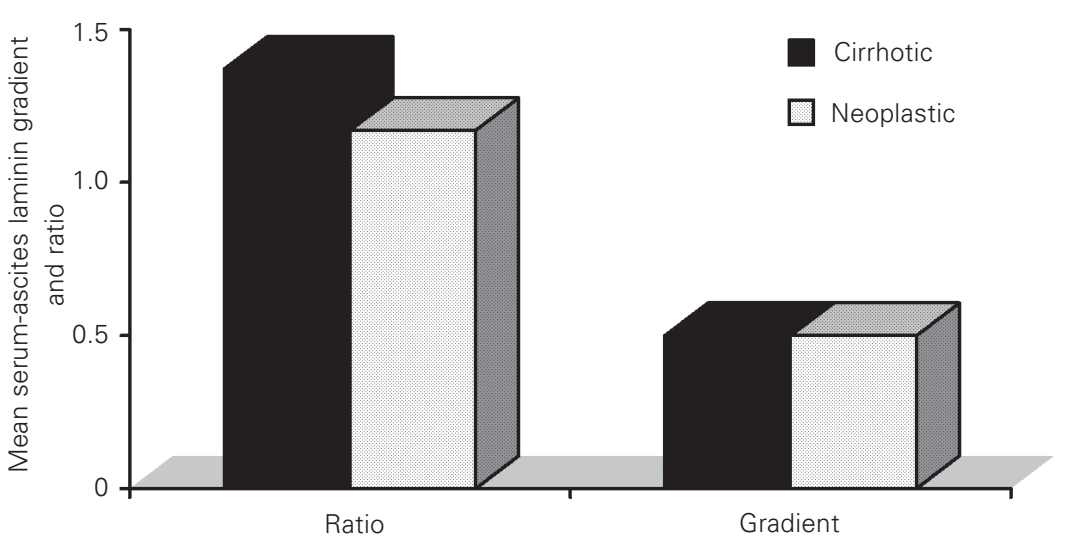

Figure 3. Serum-ascites laminin ratio and gradient for cirrhotic patients and patients with neoplasia. Mean serum-ascites laminin gradient (= serum - ascites laminin concentration) and the ratio ( $=$ serum/ascites laminin concentration) did not differ between the groups with benign (cirrhotic, $\mathrm{N}=33$ ) and neoplastic ascites $(\mathrm{N}=20$ ).

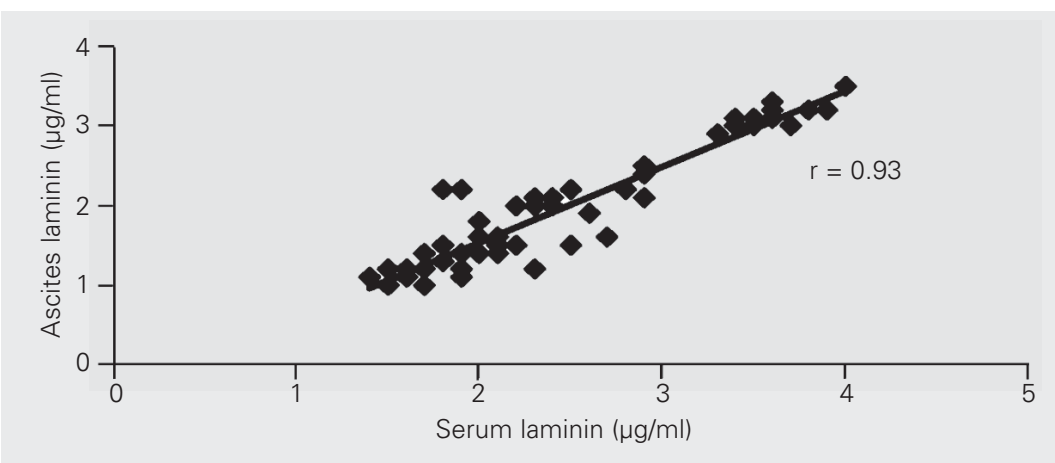

Figure 4. Correlation between serum and ascites laminin values in the group with neoplasia $(N=20)$ and the cirrhotic group $(N=33)$ calculated by Pearson's correlation coefficient $(r=$ 0.93; $P<0.0001)$. first reported by Gressner and Tittor (4), who attributed this increase to capillarization of hepatic sinusoids, since laminin levels were correlated with the portal pressure values of their patients. These findings were confirmed by others $(6,7)$ and were observed in non-cirrhotic patients with portal hypertension $(4,5)$. As mentioned before, increases in serum laminin levels are due to the formation of basement membranes in the hepatic sinusoids. However, an additional effect due to a lack of degradation of this protein by liver endothelial cells cannot be ruled out (30). On the other hand, the increased serum laminin concentration has been related to hepatic fibrosis and liver function in both human and experimental studies (4,7,31-34).

Significantly higher serum laminin levels were observed in patients with peritoneal carcinomatosis $(12-15,35,36)$. This elevated serum concentration could be due to the higher turnover of this glycoprotein in patients with advanced tumor lesions (12-15), but could also be related to a greater release of laminin molecule fragments, as reported in neoplasms $(37,38)$. Results obtained in studies on neoplastic diseases have shown that the growth of the tumor matrix and the metastasizing process lead to an increase in serum levels of basement membrane constituents with tumor progression (13).

The mean laminin values in ascites of patients with neoplasms were significantly higher than in the cirrhosis group. However, when the serum-ascites gradient and the serum/ascites ratio of the studied groups were analyzed, no significant differences could be observed between them, suggesting that these values were interdependent. This finding is contrary to that reported by Byers et al. (39), who found increases in laminin values in ascites, but not in blood of patients with ovarian tumors. In the present study, the serum laminin values were higher than those found in the ascitic fluid in every patient. Furthermore, the lack of any significant differences in the serum-ascites gradient and in 
the serum/ascites ratio, as well as the highly significant correlation between laminin levels in ascites and serum, clearly suggest that the circulating levels of this glycoprotein are the main determinant factor for the laminin levels in ascites.

On the other hand, a high correlation between serum and ascites laminin values provides further evidence of the specificity of the isolated antibody. Using the ROC curves, we could define a cut-off value for serum laminin to differentiate malignant from benign (cirrhotic) ascites. The diagnostic performance of serum laminin showed a sensitivity of $100 \%$ and a specificity of $73 \%$ for the diagnosis of neoplastic ascites.

\section{Acknowledgments}

We are grateful to Prof. Venâncio A. Ferreira Alves, Immunohistochemistry Department of Adolfo Lutz Institute, São Paulo, SP, Brazil, for the immunoperoxidase tests in rat liver.

\section{References}

1. Kleinman HK, Cannon FB, Laure GW, Hassel JR \& Aumailley M (1985). Biological activities of laminin. Journal of Cell Biology, 27: 317-325.

2. Mechan RP (1991). Receptor for laminin on mammalian cells. Federation of American Societies of Experimental Biology, 5: 25382546.

3. Engel J (1993). Structure and function of laminin. In: Rohrbach DH \& Timpl R (Editors), Molecular Cellular Aspect Basement Membrane. Academic Press, San Diego, CA, USA, 147-176.

4. Gressner AM \& Tittor W (1986). Serum laminin - Its concentration increases with portal hypertension in cirrhotic liver disease. Klinische Wochenschrift, 64: 1240-1248.

5. Parise ER \& Rosa H (1992). Serum laminin in hepatic schistosomiasis. Transactions of the Royal Society of Tropical Medicine and Hygiene, 86: 179-181.

6. Kondo M, Miszputen S, Leite-Mór MMB \& Parise ER (1995). The predictive value of serum laminin for the risk of variceal bleeding related to portal pressure levels. Hepatogastroenterology, 42: 542545.

7. Niemela O, Risteli J, Blake J, Risteli L, Compton KV \& Orrego H (1990). Markers of fibrogenesis and basement membrane formation in alcoholic liver disease. Gastroenterology, 98: 1612-1619.

8. Martinez-Hernadez A (1984). The hepatic extracellular matrix. I. Electron immunohistochemical studies in rat liver. Laboratory Investigation, 51: 57-74.

9. Martinez-Hernadez A (1985). The hepatic extracellular matrix. II. Electron immunohistochemical studies in rats with $\mathrm{CCl}_{4}$-induced cirrhosis. Laboratory Investigation, 51: 166-186.

10. Liotta LA, Rao CN \& Wewer UM (1986). Biochemical interactions of tumor cells with the basement membrane. Annual Review of Biochemistry, 55: 1037-1057.

11. Mungan U, Kirkali G, Celebi I \& Kirkali Z (1996). Significance of serum laminin $\mathrm{P} 1$ values in patients with transitional cell carcinoma of the blander. Urology, 48: 496-500.

12. Nakano T, Iwahashi N, Maeda J, Hada T \& Higashino K (1992). Serum laminin P1 in small cell lung cancer: a valuable indicator of distant metastasis. British Journal of Cancer, 65: 608-612.

13. Aboufarha KM, Menheere PP, Nieman FH, Arends JW \& Janknegt RA (1994). Value of serum laminin P1 as a diagnostic and monitoring parameter in transitional cell carcinoma of the bladder. Urologia
Internationalis, 49: 130-136

14. Matsui H \& Yudoh K (1996). Significance of serum laminin and type IV collagen levels for metastasis in murine RCT sarcoma. Tumour Biology, 17: 125-132.

15. Sidhom G \& Imam M (1999). Evaluation of serum laminin as a tumor marker in breast cancer. International Journal of Clinical and Laboratory Research, 29: 26-29.

16. Smith E \& Bentsen KD (1987). The concentration of laminin in malignant and non-malignant ascites. Journal of Hepatology, 5: S202 (Abstract).

17. Garcia-Tsao G, Grace ND, Groszmann RJ, Conn HO, Bremann MM, Patrick MJC, Morse SS \& Alberts JL (1986). Short-term effects of propanolol on portal venous pressure. Hepatology, 6: 101-106.

18. Schechter GM \& Lopes JD (1990). Two-site immunoassays for the measurement of serum laminin: correlation with breast cancer staging and presence of auto-antibodies. Brazilian Journal of Medical and Biological Research, 23: 141-149.

19. Laemmli UK (1970). Cleavage of structural proteins during the assembly of the head of bacteriophage T4. Nature, 227: 680-685.

20. Lopes JD \& Alves MJM (1983). Production of monoclonal antibodies by somatic cell hybridization. In: Morel CM (Editor), Genes and Antigens of Parasites. A Laboratory Manual. Fundação Oswaldo Cruz, Rio de Janeiro, RJ, Brazil, 386-400.

21. Bradford MM (1976). A rapid and sensitive method for the quantification of microgram quantities of protein utilizing the principle of protein-dye binding. Analytical Biochemistry, 72: 248-254.

22. Harlow E \& Lane D (1988). Antibodies. In: Nolan C \& Fergunson M (Editors), A Laboratory Manual. Cold Spring Harbor Laboratory, Cold Spring Harbor, NY, USA.

23. Rennard IS, Berg R, Martin RG, Foidart JM \& Robey PG (1980). Enzyme-linked immunoassay (ELISA) for connective tissue components. Analytical Biochemistry, 104: 205-214.

24. Avrameas S, Ternynck T \& Guesdon JL (1978). Coupling of enzymes to antibodies and antigens. Scandinavian Journal of Immunology, 7: 7-23

25. Martinez-Hernandez A, Delgado FM \& Amenta PS (1991). The extracellular matrix in hepatic regeneration localization of collagen types I, III, IV, laminin, and fibronectin. Laboratory Investigation, 64: 157166.

26. Zheng M, Cai WM, Weng HL \& Liu RH (2002). ROC curves in 
evaluation of serum fibrosis indices for hepatic fibrosis. World Journal of Gastroenterology, 8: 1073-1076.

27. Glantz SA (1981). Primer of Bio-Statistics. 4th edn. McGraw-Hill Co., Inc., New York, St. Louis, San Francisco, USA, 473.

28. Dixit SN (1985). Isolation, purification and characterization of intact and pepsin-derived fragments of laminin from human placenta. Connective Tissue Research, 14: 31-40.

29. Ohno M, Martinez-Hernandez A, Ohno N \& Kefalides NA (1986). Laminin $\mathrm{M}$ is found in placental basement membranes, but not in basement membranes of neoplastic origin. Connective Tissue Research, 15: 199-207.

30. Smerdson B, Paulsson M \& Johansson S (1989). Uptake and degradation in vivo and in vitro of laminin and nidogen by rat liver cells. Biochemical Journal, 261: 37-42.

31. Annoni G, Colombo M, Cantaluppi MC, Khlart B, Lampertico P \& Rojkind M (1989). Serum type III procollagen peptide and laminin (Lam-P1) detect alcoholic hepatitis in chronic alcohol abusers. Hepatology, 9: 693-697.

32. Schneider M, Voss B, Hogemann B, Eberhardt G \& Gerlach U (1989). Evolution of serum laminin P1, procollagen-III peptides and $\mathrm{N}$-acetyl-b-glucosaminidase for monitoring the activity of liver fibrosis. Hepatogastroenterology, 36: 506-510.

33. Zheng M, Cai W, Weng H \& Liu R (2003). Determination of serum fibrosis indexes in patients with chronic hepatitis and its signifi- cance. Chinese Medical Journal, 116: 346-349.

34. Neves LB, Catarino RM, Silva MR \& Parise ER (2003). Increased serum levels of laminin in the experimental cirrhosis induced by carbon tetrachloride. Arquivos de Gastroenterologia, 40: 173-176.

35. Rochlitz CH, Hasslacher CH, Brocks DG \& Herrmann R (1987). Serum concentration of laminin and course of the disease in patients with various malignancies. Journal of Clinical Oncology, 5: 1424-1429

36. Aoki S, Nakanishi Y, Akimoto S, Moriya Y, Yoshimura K, Kitajima M, Sakamoto M \& Hirohashi S (2002). Prognostic significance of laminin-5 gamma2 chain expression in colorectal carcinoma: immunohistochemical analysis of 103 cases. Diseases of the Colon and Rectum, 45: 1520-1527.

37. Varani J, Lovett EJ, McCoy JP, Shibata S, Maddox D, Goldstein IJ \& Wicha MS (1983). Differential expression of a laminin-like substance by high and low metastatic tumor cells. American Journal of Pathology, 111: 27-34.

38. McCoy JP, Lloyd R, Wicha MS \& Varani J (1984). Identification of a laminin-like substance on the surface of high malignant murine fibrosarcoma cells. Journal of Cell Science, 65: 139-151.

39. Byers LJ, Osborne JL, Carson LF, Carter JR, Haney AF, Weinberg JB \& Ramakrishnan S (1995). Increased levels of laminin in ascitic fluid of patients with ovarian cancer. Cancer Letters, 88: 67-72. 